\title{
MONITORING OF HEAVY METALS IN VEGETABLES AND SOIL OF AGRICULTURAL FIELDS OF KATHMANDU VALLEY
}

\author{
B. Sharma and M.K. Chettri \\ Department of Botany, Amrit Campus, P.O. Box 102 \\ Tribhuvan University, Kathmandu, Nepal \\ Email: amritcampus@ntc.net.np,mkchettri@ntc.net.np
}

\begin{abstract}
Evaluation of heavy metals in vegetables and soil of agricultural fields of Kathmandu valley was conducted. Highest accumulations of copper $\left(65.5 \mathrm{mg} \mathrm{kg}^{-1}\right)$, lead $\left(46.75 \mathrm{mg} \mathrm{kg}^{-1}\right)$ and cadmium ( $2 \mathrm{mg}$ $\mathrm{kg}^{-1}$ ) from Shankhamul; nickel (29.25 $\left.\mathrm{mg} \mathrm{kg}^{-1}\right)$ from Nakhu; cobalt (15.25 $\mathrm{mg} \mathrm{kg}^{-1}$ ) and manganese $\left(675 \mathrm{mg} \mathrm{kg}^{-1}\right)$ from Balkhu; chromium (73.75 mg kg-1) from Banasthali, zinc (162 mg kg$\left.{ }^{-1}\right)$ and iron (75636 $\mathrm{mg} \mathrm{kg}^{-1}$ ) from Khusibun were recorded in soil of agricultural fields. Highest accumulations of $\mathrm{Cu}, \mathrm{Co}$ and $\mathrm{Zn}$ were recorded in spinach and $\mathrm{Pb}$ in red radish; $\mathrm{Ni}, \mathrm{Cr}$ and $\mathrm{Fe}$ was recorded in broad leaf mustard and $\mathrm{Mn}$ in cress leaf while considering the mean of each vegetables studied. Concentration of non-essential but toxic metal like $\mathrm{Pb}$ was higher than the normal plant value $(0.1-10$ $\mathrm{mg} \mathrm{kg}{ }^{-1}$ ) in all the vegetables (except potato) collected from different sampling sites.
\end{abstract}

Key words: Heavy metals, soil, vegetables.

\section{INTRODUCTION}

Altogether fifty three heavy metals are present in nature, but only seventeen are available to living cells (Weast 1984). Among these Fe, Mo and Mn are important as micronutrients; $\mathrm{Zn}, \mathrm{Ni}, \mathrm{Cu}, \mathrm{V}, \mathrm{Co}$, $\mathrm{W}$ and $\mathrm{Cr}$ are of low importance as trace elements, but are toxic beyond limit. Heavy metals like $\mathrm{Cd}$, $\mathrm{As}, \mathrm{Hg}, \mathrm{Ag}, \mathrm{Sb}, \mathrm{U}$ and $\mathrm{Pb}$ have no biological function which is more or less toxic to living organisms (Godbold and Hüttermann 1985, Nies 1999). Heavy metals once accumulated as contaminants can neither be destroyed nor can be altered by chemical or physical means, and are circulated in the ecosystems. Heavy metals present in the atmosphere are ultimately accumulated in the soil through precipitation and fall out (Chamberlain 1960, Lagerwerff 1971, Bohn 1972, Little 1973, Buchaver 1973).

Vascular plants are endlessly exposed to shower of potentially toxic heavy metals from the air and equally absorb heavy metals from soil via root system. Tolerance of heavy metals in plants is either by detoxification mechanism or accumulation in different plant parts or cell organelles (Reilly 1969, Bringezu et al. 1999) or in vacuoles or in cell wall (Chettri et al. 2000).

Biomonitoring of toxic heavy metals $(\mathrm{Cu}, \mathrm{Pb}$, $\mathrm{Ni}, \mathrm{Co}, \mathrm{Cr}, \mathrm{Cd}, \mathrm{Zn}, \mathrm{Mn}$ ) studied in air by using mosses (Shakya et al. 2004) and lichens (Chettri et al. 2001, Devkota et al. 1997) of Kathmandu valley indicated high amount of heavy metals pollution. The main river system of Kathmandu valley is river Bagmati with its five tributaries Hanumante, Dhobi-khola, Tukucha, Bishnumati and Nakhukhola, flowing through the heart of the valley has been reported to be contaminated with heavy metals $(\mathrm{Cu}, \mathrm{Cr}, \mathrm{Pb}$ and $\mathrm{Cd}$ ) (Gautam and Agrawal 1994). Water bodies from such polluted river system are heavily used in irrigation for vegetable production in the Kathmandu. 
Based on these facts it is hypothesized that toxic heavy metals are deposited in the soil of agricultural fields and also in vegetable crops grown on such fields. Therefore this study was conducted to reveal if the level of toxic heavy metals in soils of such fields and vegetables grown in them are within the critical plant tissue concentration range or not.

\section{MATERIALS AND METHODS}

\section{Sampling sites and materials}

The present study was conducted in Kathmandu valley that has dusty and smoky atmosphere due to pollution of heavy traffic and emissions from various factories. Vegetables like Brassica juncia var. cuneifolia (broad leaf mustard), Lepidium sativum L. (cress leaf), Spinacia oleracea L. (spinach), Raphanus sativus L. (radish), Brassica rapa L. (turnip), Daucus carota L. (carrot) and Solanum tuberosum L. (potato) have been considered for the present study. The vegetables and soil samples were collected directly from 12 different sampling sites (i.e. fields) located near the main riverside of Kathmandu valley. Sampling sites, such as Banasthali, Shovabhagawati and Khusibun are located near Bishnumati river; Chhapro and Thimi near Manohora river; Shankhamul, Kusingal and Nakhu near Bagmati river; Kalopul and Ghatteculo near Dhobikhola; and Balkhu near Balkhu Khola. Representative soil samples at each sampling site were obtained by mixing soil samples collected from 10 different points, each from horizontal slices of $10-\mathrm{cm}$ depth and an area $10 \times 10 \mathrm{~cm}^{2}$. Soil samples were oven dried at $70^{\circ} \mathrm{C}-100^{\circ} \mathrm{C}$ for $72 \mathrm{~h}$ till constant dry weight (DW) and then sieved with $0.25 \mathrm{~mm}$ mesh to obtain uniform soil particles. Vegetable samples were also collected from the same sampling sites and were washed thoroughly with tap water, air-dried and then oven dried at $70^{\circ} \mathrm{C}$ for $72 \mathrm{~h}$ till constant dry weight. The soil samples after oven dry were homogenized into representative samples of each field. Similarly each parts/each vegetable were homogenized by using mortar and pestle to prepare representative samples.

\section{Sample digestion and analysis of heavy metals}

Representative samples ( $1 \mathrm{~g} \mathrm{dw}$ ) of vegetables and soil were wet digested in concentrated $\mathrm{HNO}_{3}$ (Chettri et al. 1997, Sawidis et al. 1995) at $200^{\circ} \mathrm{C}$ up to continuous heating of $4-5 \mathrm{~h}$ and the filtered through ashless filter paper (Whatman $589^{3}$ ), maintaining definite final volume with double deionized water. Concentrations of heavy metals like $\mathrm{Cu}, \mathrm{Pb}, \mathrm{Ni}, \mathrm{Co}, \mathrm{Cd}, \mathrm{Cr}, \mathrm{Zn}, \mathrm{Fe}$ and $\mathrm{Mn}$ in the filtrate were measured by using Perkin Elmer (2380) Atomic Absorption Spectrometer (AAS) with their respective wavelength (Welz 1985). For each case triplicate samples were tested. Two plant materials of NBS standards (National Bureau of Standards, USA) with Nos. 1573 (Tomato leaves) and 1575 (Pine needles) were also analyzed, following the same procedure and the metal recoveries ranged from 94 to 99 percent.

\section{RESULTS AND DISCUSSION}

Heavy metal concentrations in the soil samples collected from agricultural fields of Kathmandu valley are given in Table 1. Although soil concentrations of $\mathrm{Cu}, \mathrm{Pb}, \mathrm{Zn}$ and $\mathrm{Fe}$ in some fields and $\mathrm{Cd}$ in all fields, exceeded the normal soil values but lie below critical soil value. The soil concentration of $\mathrm{Ni}, \mathrm{Co}, \mathrm{Cr}$ and $\mathrm{Mn}$ were mostly within the normal soil value, except $\mathrm{Cr}$ at Banasthali. Soil $\mathrm{Cu}$ in Banasthali, Nakhu, Shankhamul, and Khusibun were slightly higher than normal soil value. Soil $\mathrm{Cu}$ ranged from $15 \mathrm{mg} \mathrm{kg}^{-1}$ (Kusingal) to 65. $\mathrm{mg} \mathrm{kg}^{-1}$ (Shankhamul). Soil $\mathrm{Pb}$ in Banasthali, Manohora, Nakhu, Shankhamul, Kusingal, Shovabhagawati and Balkhu exceeded normal soil value, but was below critical soil values (KabataPendias and Pendias 1984). Soil $\mathrm{Pb}$ ranged from 30.5 $\mathrm{mg} \mathrm{kg}{ }^{-1}$ (Kalopul) to $46.75 \mathrm{mg} \mathrm{kg}^{-1}$ (Shankhamul). 
Table 1. Concentrations of trace metals in soils ( $\mathrm{mg} \mathrm{kg}^{-1} \mathrm{dry}$ weight) in soils of agricultural fields, generally located near the river side of Kathmandu valley.

\begin{tabular}{|c|c|c|c|c|c|c|c|c|c|c|}
\hline $\begin{array}{l}\text { Biotops } \\
\text { numbers }\end{array}$ & Places & $\mathrm{Cu}$ & $\mathrm{Pb}$ & $\mathrm{Ni}$ & Co & $\mathrm{Cd}$ & $\mathrm{Cr}$ & $\mathrm{Zn}$ & $\mathrm{Fe}$ & Mn \\
\hline${ }^{N S V} B$ & & 30 & 35 & 50 & $1-40^{* * *}$ & 0.35 & 70 & 90 & 40000 & 1000 \\
\hline $\mathrm{uCSV}_{\mathrm{KP}}$ & & 125 & 400 & 100 & - & 8 & 100 & 400 & & 3000 \\
\hline 4 & Banasthali & $34.5 *$ & $37.25^{*}$ & 22.25 & 12 & 1.5 & $73.75^{*}$ & 70.50 & 26719 & 312 \\
\hline 8 & Chhapro & 18.48 & 32.76 & 17.36 & 10.92 & 1.68 & 31.08 & 72.24 & 22500 & 142 \\
\hline 12 & Manohora & 23.0 & $37.25^{*}$ & 14.25 & 7.5 & 1.05 & 29.0 & $117.0^{*}$ & 26928 & 48 \\
\hline 20 & Nakhu & $34.5^{*}$ & $36.5^{*}$ & 29.25 & 8.75 & 1.25 & 32.0 & 90.0 & 32670 & 443 \\
\hline 28 & Thimi & 21.32 & 31.46 & 12.5 & 6.25 & 1.04 & 29.12 & 81.12 & 18009 & $-{ }^{*}$ \\
\hline 48 & Kalopul & 20.10 & 30.5 & 12.0 & 5.75 & 1.0 & 33.5 & $141.0^{*}$ & 23661 & 127 \\
\hline 52 & Ghatteculo & 20.10 & 34.5 & 9.9 & 8.10 & 1.5 & 33.0 & $117.0^{*}$ & $61322 *$ & 141 \\
\hline 65 & Shankhamul & $65.5^{*}$ & $46.75 *$ & 19.5 & 10.75 & 2.0 & 19.75 & $115.5^{*}$ & - & 283 \\
\hline 72 & Kusingal & 15.0 & $36.0 *$ & 12.5 & 7.5 & 2.0 & 15.25 & 70.5 & 14157 & 128 \\
\hline 79 & Shovabhagawati & 23.08 & $37.44 *$ & 15.6 & 8.06 & 1.56 & 14.76 & 76.72 & 21900 & 247 \\
\hline 88 & Khusibun & $43.25^{*}$ & 33.0 & 14.75 & 8.5 & 0.75 & 33.0 & $162.0^{*}$ & 75636* & - \\
\hline 95 & Balkhu & 26.25 & $39.25^{*}$ & 27.5 & 15.25 & 1.0 & 23.75 & 79.5 & 18711 & 675 \\
\hline
\end{tabular}

*exceeded normal soil values, **Normal soil value as proposed by Swaine $1955,{ }^{\text {NSV }}$ B Normal soil value as proposed by Bowen 1979, ${ }^{\text {UCSV }}$ KP upper critical soil valuc as proposed by Kabata-Pendias and Pendias 1984.

Concentration of $\mathrm{Ni}$ and $\mathrm{Co}$ in soil lies below normal soil value. Nickel concentration in soil ranged from $9.9 \mathrm{mg} \mathrm{kg}^{-1}$ at Ghatteculo to $29.25 \mathrm{t.ng}$ $\mathrm{kg}^{-1}$ at Nakhu. Similarly soil Co ranged from 5.75 $\mathrm{mg} \mathrm{kg}{ }^{-1}$ at Kalopul to $15.25 \mathrm{mg} \mathrm{kg}^{-1}$ at Ba'thu. Soil Cd ranged from $0.75 \mathrm{mg} \mathrm{kg}^{-1}$ (Khusibun) to $2 \mathrm{mg} \mathrm{kg}$ ${ }^{1}$ (Shankhamul and Kusingal). Soil $\mathrm{Cr}$ was mostly below the normal soil value $\left(70 \mathrm{mg} \mathrm{kg}^{-1}\right)$ but it was high only at Banasthali $\left(73 \mathrm{mg} \mathrm{kg}^{-1}\right)$. Soil $\mathrm{Zn}$ in Manohora, Kalopul, Ghatteculo, Shankhamul and Khusibun exceed normal soil value and its concentration ranged from $70.5 \mathrm{mg} \mathrm{kg}^{-1}$ at Kusingal and Banasthali to $162 \mathrm{mg} \mathrm{kg}^{-1}$ at Khusibun. Iron concentration in most of the field were found kelow normal soil value $\left(40,000 \mathrm{mg} \mathrm{kg}^{-1}\right)$, except at Ghatteculo and Khusibun where it was very high with $61322 \mathrm{mg} \mathrm{kg}^{-1}$ and $75636 \mathrm{mg} \mathrm{kg}^{-1}$, respectively and lowest in Thimi $\left(18009 \mathrm{mg} \mathrm{kg}^{-1}\right)$. Soil Mn is low (48 $\mathrm{mg} \mathrm{kg}^{-1}$ ) at Manohora and is high (675 $\mathrm{mg} \mathrm{kg}^{-1}$ ) at Balkhu, and are lying below normal soil value. Table 1, indicates increased trend of heavy metals contamination in soil e.g. in Banasthali with $\mathrm{Cl}, \mathrm{Pb}$, $\mathrm{Cr}$; in Manohora with $\mathrm{Pb}$ and $\mathrm{Zn}$; in Nakhu with $\mathrm{Cu}$ and $\mathrm{Pb}$; in Kalopul and Ghatteculo with $\mathrm{Zn}$; in Shankhamul with $\mathrm{Cu}, \mathrm{Pb}, \mathrm{Cd}$ and $\mathrm{Zn}$; in Kusingal, Shovabhagawati and Balkhu with $\mathrm{Pb}$; in Khusibun with $\mathrm{Cu}, \mathrm{Zn}$ and $\mathrm{Fe}$. The high concentrations of heavy metals in the agricultural fields of Kathmandu valley may be due to precipitation or fall out of atmospheric pollution, as has been pointed out by biomonitoring studies using mosses and lichen (Shakya ct al. 2004, Chettri et al. 2001, Devkota et 
al. 1997). Besides this, heavy metals must have been added due to use of polluted river water for irrigation (Gauatm and Agrawal 1994) or due to use of chemical fertilizer (Sharply and Menzel 1987, Galloway et al. 1982). In some places like Shankhamul concentrations of $\mathrm{Cu}, \mathrm{Pb}$ and $\mathrm{Cd}$ in the soil are high but accumulation in vegetables are low. The possible reason for this may be due to soil factors (soil pH, organic matter, clay contents etc.) which vary in different area. Increased organic matter (Zimdahl \& Foster 1976, Gadd and Griffths 1978, Bassuk 1986) and increased clay particles (Hodgson 1963) can bind metal cations and become unavailable to plants and organisms in the soil.

Accumulation of heavy metals in edible portions of vegetables

Heavy metals present in edible portions of studied vegetables are given in Table $2 . \mathrm{Cu}$ concentration in broad leaf mustard (17.75 $\mathrm{mg} \mathrm{kg}^{-1}$ ) from Khusibun and spinach from most of the sampling sites was slightly above the normal plant value. Among the leafy vegetables, highest $\mathrm{Cu}$ accumulation (25 $\mathrm{mg} \mathrm{kg}^{-1}$ ) was found in spinach leaves (Table 2.) from Shankhamul area. Bioaccumulation of $\mathrm{Cu}$ was highest in spinach leaves $>$ cress leaf $>$ broad leaf mustard $>>$ turnip $>$ carrot $>$ red radish $>$ white radish $=$ potato tuber Copper accumulation was less in root of carrot (4-6.5 $\left.\mathrm{mg} \mathrm{kg}{ }^{-1}\right)$ and radish $\left(3.5 \mathrm{mg} \mathrm{kg}^{-1}-5.75 \mathrm{mg} \mathrm{kg}{ }^{-1}\right.$ than in most leafy vegetables. Within the same environment different vegetables have different accumulation. This may be due to differences in ligands at the binding sites of each vegetable. Besides this, high $\mathrm{pH}$, lime, organic matter and phosphate reduce its uptake (Streit and Stumm 1993).

Lead accumulation in most vegetable crops except potato exceeds normal plant tissue concentration (Table 2). Highest accumulation of $\mathrm{Pb}$ was observed in red radish and lowest in potato. High $\mathrm{Pb}$ accumulation above $20 \mathrm{mg} \mathrm{kg}^{-1}$ was observed in all vegetables except potato. Although $\mathrm{Pb}$ is immobile in soil (Streit and Stumm 1993), there was high $\mathrm{Pb}$ accumulation in both leafy and root vegetables, and clearly indicates that green and leafy vegetables of Kathmandu valley accumulate $\mathrm{Pb}$ through both root uptake and atmospheric fall out. Deposition of $\mathrm{Pb}$ in vegetables is directly related to the exhaust emissions of leaded gasoline on one side and wear and tear of tires on the other sides (Djingova and Kuleff 1993).

Among the leafy vegetables, cress leaf showed high $\mathrm{Cd}$ accumulation where as turnip showed (Table 2) high accumulation among roots. Although most of leafy vegetables showed more $\mathrm{Cd}$ accumulation compared to roots, even bioaccumulation of $\mathrm{Cd}$ in spinach leaf is mostly greater than in soil showing tendency of hyperaccumulation. The plant $\mathrm{Cd}$ values are within the ranges of normal plant values. Chromium accumulation in all vegetables was found within normal plant value and ranges from $0.25 \mathrm{mg}$ $\mathrm{kg}^{-1}$ to $4.75 \mathrm{mg} \mathrm{kg}^{-1}$ in spinach. This might be due to very lower chromate uptake which occurs only in hexavalent form and is rapidly reduced to immobile trivalent form (Streit and Stumm 1993) in the soil.

Hyperaccumulation (higher than soil values) of $\mathrm{Zn}$ was also seen in red radish of Kusingal, Shovabhagawati and Khusibun, but not observed in white radish. Similarly, hyperaccumulation of $\mathrm{Zn}$ in plant tissue was also observed in broad leaf mustard collected from Kusingal, cress leaf from. Khusibun and spinach from Shankhamul. In most of the cases $\mathrm{Zn}$ hyperaccumulation was observed exceeding critical plant concentration of $200 \mathrm{mg}$ $\mathrm{kg}^{-1}$ (Davis and Beckett 1978). Zinc accumulation in spinach collected from Shankhamul showed 462 $\mathrm{mg} \mathrm{kg}^{-1}$ which exceeds critical plant tissue concentration. The possible reason for hyperaccumulation of $\mathrm{Zn}$ in plant tissue is due to easy transportation from the roots into the aerial parts. 
Table 2. Concentrations of accumulated heavy metals in edible vegetable parts and soils (mean value in $\mathrm{mg} \mathrm{kg-}{ }^{1} \mathrm{DW}$ ).

\begin{tabular}{|c|c|c|c|c|c|c|c|c|c|}
\hline $\begin{array}{l}\text { Vegetable parts/ } \\
\text { Places }\end{array}$ & $\mathrm{Cu}$ & $\mathrm{Pb}$ & $\mathrm{Ni}$ & Co & $\mathrm{Cd}$ & $\mathrm{Cr}$ & $\mathrm{Zn}$ & $\mathrm{Fe}^{*}$ & Mn \\
\hline${ }^{\mathrm{NPV}} \mathbf{A}$ & $5-15$ & $0.1-10$ & $1-2.7$ & - & $.1-2.4$ & $0.2-10$ & $20-400^{\text {B }}$ & 140 & - \\
\hline${ }^{\mathrm{RVCPC}} \mathbf{K P}$ & $20-100$ & $20-300$ & $10-100$ & - & $5-30$ & $5-30$ & $100-400$ & - & $300-500$ \\
\hline \multicolumn{10}{|l|}{ Broadleaf } \\
\hline Thimi & 6.5 & $25.25^{*}$ & 7 & 3.5 & 1 & 2.75 & 57 & $6284^{*}$ & 67 \\
\hline Manohora & 7.75 & $23^{*}$ & 4.25 & 1.25 & 1 & 4.25 & 49.5 & $573 *$ & 42.25 \\
\hline Kalopul & 8.0 & 16.50 & 3.25 & 6 & 0.5 & 1.75 & 51 & $4167^{*}$ & 25.75 \\
\hline Banasthali & 3.0 & 17.75 & 4.75 & 1.5 & 0.75 & 4.5 & 37.5 & $5859^{*}$ & 27.25 \\
\hline Shankhamul & 11.25 & $28.25 *$ & 5 & 2.75 & 1.5 & 2.25 & 88.5 & $5463 *$ & 38 \\
\hline Kusingal & 9.25 & $31.75^{*}$ & 6.75 & 3.75 & 1.5 & 2.25 & 118.25 & $6336 *$ & 30 \\
\hline Shovabhagawati & 9.75 & $28.75^{*}$ & 4.25 & 2.25 & 1.25 & 3.25 & 54 & $4851^{*}$ & 37.25 \\
\hline Khusibun & $17.75^{*}$ & $34.75^{*}$ & 4.5 & 0.25 & 0.75 & 2.25 & 105 & $8361 *$ & 74.5 \\
\hline Balkhu & 11.5 & 15 & 7 & 3 & 0.75 & 3 & 75 & $7866^{*}$ & 73.75 \\
\hline Mean & 9.42 & 24.56 & 5.19 & 2.69 & 1.00 & 2.92 & 70.64 & 5528.89 & 46.19 \\
\hline \multicolumn{10}{|l|}{ Cress leaf } \\
\hline Thimi & 7.25 & $29 *$ & 3.5 & 3.25 & 0.5 & 3.5 & 52.5 & $526.5^{*}$ & 72.75 \\
\hline Manohora & 9.5 & $22 *$ & 2.75 & 2 & 1.5 & 1.5 & 84 & $1647^{*}$ & 48 \\
\hline Khusibun & 13.26 & $31.72 *$ & 6.24 & 2.08 & 1.3 & 3.12 & 363.48 & $4062^{*}$ & 187.2 \\
\hline Mean & 10.00 & 27.57 & 4.16 & 2.44 & 1.10 & 2.71 & 166.66 & 2078.50 & 102.65 \\
\hline \multicolumn{10}{|l|}{ Spinach } \\
\hline Thimi & 14.75 & $37.5^{*}$ & 6 & 4 & 1.25 & 4.75 & 79.5 & $3735^{*}$ & 90.75 \\
\hline Banasthali & 13.25 & $22.25^{*}$ & 4 & 3 & 0.75 & 2.75 & 96 & $5157^{*}$ & 98.5 \\
\hline Chappro & 14.85 & 17.05 & 3.85 & 4.4 & 1.1 & 1.93 & 247.5 & $15939^{*}$ & 111.1 \\
\hline Shakhamul & $25^{*}$ & 12.75 & 7.25 & 1.25 & 0.5 & 2.5 & $462 *$ & 6993* & 72 \\
\hline Shovabhagawati & 7.5 & 7 & 2.5 & 1.5 & 0.25 & 0.25 & 150 & $171^{*}$ & 5 \\
\hline Manohora & $15.6^{*}$ & $31.98^{*}$ & 5.46 & 2.6 & 1.04 & 3.12 & 96.72 & $828.36 *$ & 3.12 \\
\hline Mean & 15.16 & 21.42 & 4.84 & 2.79 & 0.82 & 2.55 & 188.62 & $5470^{*}$ & 63.41 \\
\hline \multicolumn{10}{|l|}{ Carrot } \\
\hline Chappro & 6.5 & 19.25 & 0.25 & 0.75 & 0.25 & 1.25 & 30 & $220.5^{*}$ & 9.75 \\
\hline Banasthali & 4 & 17.75 & 3.25 & 2 & 0.25 & 0.25 & 43.5 & $210^{*}$ & 10.5 \\
\hline Manohora & 5.5 & $20.5^{*}$ & 3.5 & 2 & 0.25 & 0.25 & 34.5 & $396^{*}$ & 11.75 \\
\hline Ghatteculo & 4.25 & $23.5^{*}$ & 3 & 0.25 & 1.25 & 0.75 & 57 & $450^{*}$ & 127.75 \\
\hline Shakhamul & 5.5 & $20.75^{*}$ & 5.5 & 2.2 & 1.1 & 0.28 & 112.6 & $2039.4 *$ & 26.13 \\
\hline Mean & 5.15 & 20.35 & 3.10 & 1.44 & 0.62 & 0.56 & 55.52 & $663 \%$ & $\begin{array}{c}37.18 \\
\text { contd.... }\end{array}$ \\
\hline
\end{tabular}




\begin{tabular}{|c|c|c|c|c|c|c|c|c|c|}
\hline \multicolumn{10}{|l|}{ Radish $\left({ }^{\circledR}\right.$} \\
\hline Kusingal & 3.75 & $20 *$ & 0.5 & 2.25 & 0.25 & 0.75 & 102 & $612 *$ & 2 \\
\hline Shovabhagawati & 5.75 & $33.75 *$ & 3.25 & 2.25 & 1.25 & 0.75 & 162 & $1971 *$ & 18.5 \\
\hline Khusibun & 5.2 & $39.05^{*}$ & 2.8 & 2.86 & 0.26 & 0.78 & 92.04 & $1263.6 *$ & 26.78 \\
\hline Mean & 4.90 & 30.93 & 2.18 & 2.45 & 0.59 & 0.76 & 118.68 & $1282 *$ & 15.76 \\
\hline \multicolumn{10}{|l|}{ Radish (w) } \\
\hline Thimi & 3.75 & $22.5^{*}$ & 3.25 & 0.25 & 0.25 & 1.25 & 40.5 & $873^{*}$ & 13 \\
\hline Ghatteculo & 3.75 & $27.75^{*}$ & 6 & 2 & 0.75 & 0.75 & 147.5 & $2331^{*}$ & 14 \\
\hline Shovabhagwati & 3.5 & $28.82 *$ & 2 & 0.25 & 0.25 & 1.5 & 49.5 & $153 *$ & 14 \\
\hline Mean & 3.67 & 26.36 & 3.75 & 0.83 & 0.42 & 1.17 & 79.17 & 1119 & 13.67 \\
\hline \multicolumn{10}{|l|}{ Turnip } \\
\hline Thimi & 7.75 & 16.25 & 1.5 & 4.25 & 0.75 & 0.5 & 99 & $390 *$ & 21 \\
\hline Manohora & 5.25 & $24.75 *$ & 4.25 & 0.75 & 0.25 & 1.25 & 48 & $3429 *$ & 27.27 \\
\hline Kusingal & 3 & $25.25^{*}$ & 0.5 & 1.75 & 1 & 0.25 & 73.5 & $342 *$ & 8.75 \\
\hline Mean & 5.33 & 22.08 & 2.08 & 2.25 & 0.67 & 0.67 & 73.5 & $1387 *$ & 19 \\
\hline \multicolumn{10}{|l|}{ Potato } \\
\hline Sankhu & 4 & 5.75 & 1.5 & 1.5 & 0.25 & 1.25 & 45 & 87 & 11.5 \\
\hline Pachakhal & 3.75 & 9.75 & 0.25 & 1.5 & 0.7 & 0.25 & 52.5 & 108 & 8.25 \\
\hline Manohora & 3.25 & 4.75 & 0.25 & 2.5 & 0.5 & 1.25 & 42 & 87 & 18.25 \\
\hline Mean & 3.67 & 6.75 & 0.67 & 1.83 & 0.48 & 0.92 & 46.5 & 94 & 12.67 \\
\hline
\end{tabular}

*exceeded normal plant value, ${ }^{\mathrm{NPV}}$ A normal plant value of Alloway (1968), ${ }^{\mathrm{B}}$ Bowen (1979), ${ }^{\mathrm{RVCPC}} \mathrm{KP}$ Range value of critical plant concentration of Kabata-Pendias and Pendias (1992).

Although, Ni accumulation is higher than the normal plant value, but is below the value of critical plant concentration $\left(10 \mathrm{mg} \mathrm{kg}^{-1}\right)$. High mean value of $\mathrm{Ni}$ content was seen in leafy vegetables than in roots. Cobalt accumulation ranged from $0.25 \mathrm{mg} \mathrm{kg}^{-1}$ to $6.0 \mathrm{mg} \mathrm{kg}^{-1}$ in broad leaf mustard. Highest mean value of Co was observed in spinach.

Accumulation of $\mathrm{Fe}$ is extremely higher in all vegetables than normal plant value $\left(140 \mathrm{mg} \mathrm{kg}^{-1}\right)$, except potato. Fe concentration is high in the order of broad leaf mustard $>$ spinach $>$ cress leaf $>$ turnip $>$ radish $>$ carrot $>$ potato. High $\mathrm{Fe}$ accumulation above the normal plant concentration in all vegetable crops may be due to bioaccumulation of it as iron phosphate in the vasscular bundles along the veins of a leaf. Sometime the accumulation of iron phosphate is in such an extent that the adjoining tissues become even markedly deficient in iron (Streit and Stumm 1993). Water logged condition and mobile organic complex, low organic matter and chelates increase the Fe uptake.

Among all the studied vegetables, bioaccumulation of $\mathrm{Mn}$ was high (ranges from 48 $\mathrm{mg} \mathrm{kg}{ }^{-1}$ to $187.2 \mathrm{mg} \mathrm{kg}^{-1}$ ) in cress leaf. In all the plants $\mathrm{Mn}$ concentration was found to be below the critical plant concentration.

As the vegetables under study are herbaceous species and accumulated high amount of $\mathrm{Pb}, \mathrm{Zn}$ and $\mathrm{Fe}$ in most cases, therefore, can be used for monitoring air/soil pollution as suggested by Ernst and Leloup (1987). Root of carrot, radish and turnip also accumulated different heavy metals (especially $\mathrm{Pb}$ ) and supports the view of Witting (1992) that underground parts may act as a suitable 
bioindicators, and is possibly due to a moderate mobility of Fe, Mn, Zn, Cu and Mo (Ziegler 1988) in the xylem and phloem of root and their accumulation in parenchymatous tissues of cortex layer (Kelepertsis and Andrulakis 1983).

For bioaccumulation of heavy metals in different vegetables various mechanisms like binding metal with organic acids, proteins or other ligands (Lee et al. 1978, Rauser and Curvetto 1980, Godbold et al. 1984) can be speculated. Similarly, adsorption of metals in different plant parts like cell wall, middle lamella or cell organelles (Reilly 1969, Barcelo and Poschenrieder 1990, Bringezu et al. 1999, Chettri et al. 2000) can be suggested for their bioaccumulation.

\section{CONCLUSIONS}

From the present study it can be concluded that in some agricultural fields the concentration of $\mathrm{Cu}, \mathrm{Pb}, \mathrm{Cd}, \mathrm{Zn}$ and $\mathrm{Fe}$ are above the normal soil value and reflect the possibility of soil pollution. Accumulation of $\mathrm{Pb}$ in both leafy and underground vegetables (except in potato tuber), indicated that the highly toxic metal $\mathrm{Pb}$ has been entering our food chain through vegetables. Although the green vegetables are the good sources of $\mathrm{Zn}, \mathrm{Cu}, \mathrm{Fe}$ necessary for our good health, but by the accumulation of toxic metals like $\mathrm{Pb}$ and $\mathrm{Cd}$, the essential micronutrients would be deficient in our daily diet. In heavy metal contaminated areas leafy vegetables, which are good accumulator, should be avoided for commercial farming and should be substituted by non-accumulator plant like potato.

\section{ACKNOWLEDGEMENTS}

The authors acknowledge Dean Office, Institute of Science and Technology, Tribhuvan University, Kirtipur for providing financial support for the work and Department of Botany, Amrit Campus for providing laboratory facilities.

\section{REFERENCES}

Alloway, W.H. 1968. Agronomic controls over environmental cycling of trace elements. Advances in agronomy 20:235-274.

Barcelo, J. and Ch. Poschenrieder. 1990. Plant water relations as affected by heavy metal stress: a review. J. Plant Physiol. 125:17-25.

Bassuk, N.L. 1986. Reducing Lead uptake in Lettuce. Hort. Sci. 21:993-995.

Bohn, H.L. 1972. Soil adsorption of air pollutants. J. Environ. Qual. 1:372-377.

Bowen, H.J.M. 1979. Environmental Chemistry of the element. Academic Press, London.

Bringezu, K., O. Lichtenberger, I. Leopold and D. Neumann. 1999. Heavy metal tolerance of Silene vulgaris. Journal of Plant Physiology 154:536-546.

Buchaver, M.J. 1973. Contamination of soil and vegetation near a zinc smelter by zinc, cadmium, copper and lead. Environ. Sci. Technol. 7:131-135.

Chamberlain, A.C. 1960. Aspects of the deposition of radioactive and other gases and particles. Int .J. Air pollution 3:63-88.

Chettri, M.K., K.B. Thapa., K. Paudel and B. Acharya. 2001. Biomonitoring of toxic heavy metals in Kathmandu valley using lichens. Ecoprint 8: 69-76.

Chettri, M.K., T. Sawidis and E.W. Chmielewska. 2000. Localization of heavy metals in lichen thalli: an ultrastuuctural approach. Bios (Macedonia, Greece) 5:61-75.

Chettri, M.K., T. Sawidis and S. Karataglis. 1997. Lichens as a tool for biogeochemical prospecting. Ecotoxicology and Environ. Safety 38(1):322-335.

Davis, R.D. and P.H.T. Beckett. 1978. Upper critical levels of toxic elements in plant. 11. 
critical levels of $\mathrm{Cu}$ in young barley, wheat, rape, lettuce and rye grass and of $\mathrm{Ni}$ and $\mathrm{Zn}$ in young barley and rye grass. New Phyto. 80:2332.

Devkota, B., C. Bania and G.P.S. Ghimire. 1997. Studies on air pollution due to heavy metals $(\mathrm{Cd}$ and $\mathrm{Pb}$ ) using lichens as biomonitors. Ecoprint 4:61-68.

Djingova, R. and I. Kuleff. 1993. Monitoring of heavy metal pollution by Taraxacum officinale. In: Plants as Biomonitors. (ed.) Markert, B. VCH. Weinheim / New York / Basel / Cambridge / Tokyo. pp. 435-460.

Ernst, W.H.O. and S. Leloups. 1987. Perennial herbs as monitor for moderate levels of metal fall out. Chemosphere. 16:233-258.

Gadd, G.M. and A.J. Griffiths. 1978. Microorganisms and heavy metal toxicity. Microbial Ecology 4:303-317.

Galloway, J.N., J.D. Thornton, S.A. Norton, H.L. Volchok and R.A. McLean. 1982. Trace metal in atmospheric deposition: a review and assessment. Atmosph. Environ. 16:1677-1700.

Gautam, S.K. and V.P. Agrawal. 1994. Measurements of heavy metals in Bagmati river and its tributaries flowing through Kathmandu valley. Ind National Conference of Science and Technology. June 8-11, 1994.

Godbold, D.L. and A. Huttermann. 1985. Effect of zinc, $\mathrm{Cd}$ and $\mathrm{Hg}$ on root elongation of Picea abies (Karst) seedlings, and the significance of these metals to forest die back. Environ. Pollut. Ser. A 38:375-381.

Godbold, D.L., W.J. Horst, J.C. Collins, D.A. Thurman and H. Marschner. 1984. Accumulation of zinc and organic acids in roots of zinc tolerant and non-tolerant ecotypes of Descampsia caespitosa. Journal of Plant Phsiology 116:59-69.
Hodgson, J.F. 1963. Chemistry of the micronutrient elements in soils. Adv. Agron. 15:119-159.

Kabata -Pendias, A. and H. Pendias. 1984, 1992. Trace elements in soils and plants. $1^{\text {st }}$ and 2 nd edn CRC press, Boca Raton, Florida.

Kelepertsis, A.E. and I. Andrulakis. 1983. Geobotany-biochemistry for mineral exploration of sulphide deposits in Northen Grecce-heavy metal accumulation by Rumex acetocella L. and Minuartia verna (L.) Hiern J. Geochem. Explore. 18:267-274.

Langerwerff, J.V. 1971. Uptake of cadmium, lead and zinc by radish from soil and air. Soil Sci. 3:129-133.

Lee, J., R.D. Reeves, R.R. Brooks and T. Jaffre. 1978. The relation between nickel and citric acid in some nickel accumulating plants. Phytochemistry 17:1033-1035.

Little, P. 1973. A study of heavy metal contamination of lead surfaces. Environ. Pollut. 5:159-172.

Nies, D.H. 1999. Microbial heavy metal resistance. Applied Microbiology Biotechnology 51:730750

Rauser, W.E. and N.R. Curvetto. 1980. Metal thionein occurs in roots of Agrostis tolerant to excess copper. Nature 287:563-564.

Reilly, C. 1969. The uptake and accumulation of copper by Becium homblei (De Wild) Duvig and Plancke,- New phytol. 68:1081-1087.

Sawidis, T., M.K. Chettri, G. Zachariadis, J. Straits and M.R.D. Seaward. 1995. Heavy metals bioaccumulation in lichens from Macedonia in North Greece. Toxicol. Environ. Chem. 50:157-166.

Shakya, K., M.K. Chettri and T. Sawidis. 2004. Appraisal of some mosses for biomonitoring air 
borne heavy metals in Kathmandu valley. Ecoprint 11:35-49.

Sharply, A.N. and R.G. Menzel. 1987. The impact of soil and fertilizers phosphorus on the environment. Adv. Agron. 41:297-324.

Streit, B. and W. Stumm. 1993. Chemical properties of metals and the process of bioaccumulation in terrestrial plants. In: Plants as Biomonitors. (ed.) Markert, B. VCH. Weinheim / New York / Basel / Cambridge / Tokyo. pp. 415-434.

Swaine, D.J. 1955. The Trace Element Content of Soil. Commonwealth Bur. Soil. Sci. Tech. Comm., No 48, London .
Weast, R.C. 1984. CRC Handbook of Chemistry and Physics. 64th edn. Boca Raton CRC Press.

Welz, B. 1985. Atomic Absorption Spectrometry. VCH, Weinheim, Germany.

Witting, R. 1992. Die Eignung der Krautschcht von Waldern Veroffentl. Naturschutz Landschaftspflege, Beitheft 64:134-145

Ziegler, H. 1988. Weg der Schadstoffe in der Pflanfe, pp.35-46. in: Hock, b, Elstner e, Schadvirkungenand Pflanzen. 2. Aufl BI Wissenchaftaveslag, Mannheim.

Zimdahl, R.L. and J.M. Foster. 1976. The influences of applied phosphorous, manure or lime on uptake of lead from soil. $J$ Environ Qual. 5:31-34. 